\title{
Pandemi Covid19 dan Pengaruh Terhadap Keputusan Pembelian di Dpawon Katering Jakarta
}

\author{
Ayu Fatika Lorine, Agus Sudono, Dias Pratami Putri \\ Indonesia University of Education, Jl. Dr. Setiabudhi No. 229, Bandung 40154, Indonesia \\ *Corresponding Author E-mail: ayufatikal@student.upi.edu
}

\begin{abstract}
Dpawon katering merupakan katering Jakarta yang menyediakan layanan katering Jabodetabek, khususnya katering Jakarta Barat. Salah satu fokus utama layanan yang diberikan oleh Dpawon Katering ini adalah katering kantoran. Tujuan dari penelitian ini adalah untuk mengetahui pengaruh bauran pemasaran yaitu (produk, harga, lokasi, promosi, proses, orang, dan bukti fisik) terhadap keputusan pembelian di Dpawon Katering Jakarta pada masa pandemi covid 19. Jenis penelitian yang digunakan adalah penelitian kuantitatif dengan metode analisis statistik deskriptif dan verifikatif. Populasi dalam penelitian ini adalah konsumen yang sudah penah menggunakan jasa dan sudah pernah mengkonsumsi produk dari Dpawon katering. Responden penelitian ini berjumlah 100 orang. Teknik pengumpulan data menggunakan metode penyebaran kuesioner kepada konsumen Dpawon katering. Teknik analisis data menggunakan regresi linear berganda. Hasil penelitian menunjukkan bahwa bauran pemasaran berpengaruh positif terhadap keputusan pembelian. Sehingga dapat disimpulkan variabel bauran pemasaran yang berpengaruh positif dan signifikan terhadap keputusan pembelian ialah variabel produk, proses, dan bukti fisik.
\end{abstract}

Keywords: Bauran Pemasaran, Keputusan Pembelian

First Received: Agustus 2014 Revised: September 2014

Accepted: Oktober 2014

Final Proof Received: December 2014

Published: December 2014 


\section{Introduction}

Pada akhir 2019, dunia merasa ngeri dengan informasi tentang virus corona yang pertama kali ditemukan di Wuhan China. Coronavirus Disease 2019 atau Covid19 merupakan virus klasifikasi baru, virus corona ditandai dengan gejala ringan berupa demam $38^{\circ}$, sesak napas, batuk sehingga penyebaran virus ini sangat cepat dan meluas yang mengakibatkan pandemi global hingga saat ini.

Covid19 berdampak pada aktivitas di seluruh jagat raya, dan Indonesia. Sehingga penerapan kebijakan PSBB di setiap daerah yang berdampak pada berkurangnya kegiatan yang dilakukan oleh masyarakat sekitar. Salah satu dampak covid19 adalah industri makanan dan minuman, yaitu di sektor katering.

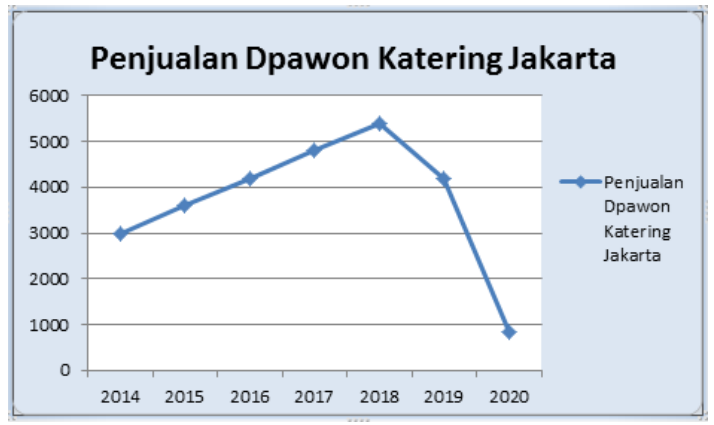

Gambar 1. Penjualan Dpawon Katering Jakarta

Bersumber gambar 1 diperoleh data penjualan di Dpawon Catering meningkat dari 2014 hingga 2018. Pada 2019 penjualan turun 4,2 miliar, sehingga penurunannya dikatakan tidak terlalu besar. Namun pada 2020 penurunannya sangat drastis, terhitung sejak Januari hingga Februari jumlahnya turun 250 juta bulan. Kemudian pada Maret, dampak virus corona turun tajam menjadi 50 juta bulan.

Dpawon Catering Jakarta adalah perusahaan katering yang menyediakan berbagai layanan, salah satu layanan fokus utama yang disediakan oleh katering Dpawon adalah kantor katering yang berlokasi di Cengkareng, Jakarta
Barat yang berdiri sejak 2010. Peningkatan dan penurunan omzet penjualan katering dpawon dipengaruhi oleh virus corona yang memberlakukan PSBB, sehingga mempengaruhi proses keputusan pembelian.

Keputusan pembelian menjadi pertimbangan untuk memilih tindakan melalui dua opsi atau lebih (Indriasari, 2017). Pemilihan opsi ini dipengaruhi oleh beberapa faktor, yaitu campuran pemasaran. Berdasarkan permasalahan tersebut, para peneliti bertujuan untuk membuktikan pengaruh marketing mix terhadap keputusan pembelian selama pandemi covid19 di Dpawon Catering Jakarta.

\section{Literature Review}

\subsection{Bauran Pemasaran}

Bauran pemasaran dapat mendukung perusahaan untuk memastikan bagian pemasarannya, sebagai akibatnya memperkuat kedudukan bisnisnya dipasar dan memajukan kepuasan kosumen (Shahhosseini \& Tohidy A, 2011).

Menurut (Kotler \& Armstrong, 2008, hlm.62) mengungkapkan tentang campuran pemasaran adalah "gagasan alat pemasaran yang dapat merumuskan strategi yang ditargetkan dan terintegrasi oleh perusahaan untuk membantu pelanggan yang telah menjadi target pasar. Campuran pemasaran dibagi menjadi 4 kategori utama yang disebut 4P, yaitu : produk, harga, tempat, dan promosi. Sementara itu, menurut Hurriyati (2005) yang disarankan dalam pemasaran layanan perlu diperluas dengan menambahkan faktor mix pemasaran non tradisional yaitu proses, orang, dan bukti fisik sehingga menjadi tujuh unsur.

\subsection{Produk}

Kotler dan Armstrong (2008, hlm. 266) adalah "barang yang ditawarkan ke pasar untuk perhatian, pembelian, kepemilikan, penggunaan atau 
penggunaan sebagai akibat dari memenuhi kepentingan atau harapan konsumen". Menurut Shinta (2011, hlm. 76) menjelaskan "produk mengacu pada apa yang dapat dibeli di pasar baik produk nyata atau produk (layanan) yang tidak nyata, akibatnya dapat memenuhi kebutuhan dan keinginan pasar".

\subsection{Harga}

Budi in (Wulan, 2016) merupakan indikator yang perlu diperhatikan karena ketika konsumen memilih suatu produk, dan harga dapat memenangkan hati dalam pengambilan keputusan konsumen dan calon konsumen. Menurut Shinta, 2011, hlm. 102) harga tersebut adalah "poin yang dinyatakan dalam format rupiah untuk omset atau transaksi atau sejumlah uang yang harus dibayar oleh nasabah untuk mendapatkan produk dan layanan".

\subsection{Tempat}

Kotler (2009, hlm. 126) adalah "berbagai kegiatan yang dilakukan oleh perusahaan untuk memfasilitasi pembuatan barang dan siap dipasarkan untuk menyasar konsumen". Menurut Shinta (2011, hlm.90) menjelaskan "tempat yang sama pada saluran distribusi dan lokasi, dalam saluran distribusi pemasaran adalah ikatan melalui perdagangan dan pembelian yang diproses bersama untuk memobilisasi produk dan layanan dari produsen ke pelanggan".

\subsection{Promosi}

Kotler (2009, hlm. 28) adalah "kegiatan pemasaran yang bertujuan untuk merangsang konsumen ke lebih banyak pembeli, memberikan kecepatan yang lebih cepat dan lebih besar untuk beberapa produk atau layanan yang telah disediakan". Promosi merupakan rangkaian kegiatan yang dirancang untuk berkomunikasi, memberikan pengetahuan dan meyakinkan pembeli produk sehingga ia membeli, dapat mengenali keunggulan produk, dan menggunakan produk Suryadi di (Pertiwi et al., 2016).

\subsection{Proses}

Proses menyebutkan bagaimana layanan menyiapkan layanan organisasi seperti ketangkasan dan kecermatan proses layanan yang diberikan memainkan kontribusi dalam mempengaruhi respons konsumen. Ketangkasan dan kecermatan proses ini harus didukung oleh teknologi yang tepat sehingga perubahan proses dapat dilakukan. Teknologi memiliki dampak yang luar biasa pada kemajuan opsi pengiriman layanan, menempatkan output yang efektif dan memberikan layanan yang berguna bagi konsumen (Naibaho et al., 2020).

\subsection{Orang}

Halim et.al (2021, hlm.6) adalah "integrasi target pasar dan orang-orang yang langsung terikat dengan bisnis, ketika bisnis mendapatkan orang-orang yang benar-benar percaya diri pada produk dan layanan yang diciptakan oleh bisnis tertentu, sehingga karyawan cenderung berjalan dalam yang terbaik".

\subsection{Bukti Fisik}

Halim et.al (2021, hlm.6) menjelaskan "dalam industri jasa, harus ada pembenaran bahwa layanan telah banyak digunakan, ini disebut kesaksian/bukti konsumen yang menggunakan layanan tersebut. Selain itu, bukti berkaitan dengan cara pasar memandang perusahaan dan produknya". According to Tresyanto \& Panjaitan (2017, hlm. 26) bahwa bukti fisik adalah "lingkungan yang menciptakan layanan yang dibuat dan berinteraksi dengan pelanggan".

\subsection{Keputusan Pembelian}

Sudirman Sudirman (2020, hlm. 30) "Keputusan pembelian merupakan 
rangkaian prosedur kognitif yang perlu diterapkan masyarakat dalam memilih barang yang akan dibeli akibatnya akan memotivasi masyarakat untuk membeli barang tersebut". Keputusan pembelian adalah teknik memilih tanpa pandang bulu untuk dibeli, termasuk mencari tahu barang mana yang akan dibeli atau yang tidak lagi dibeli. Keputusan pembelian untuk memutuskan pelanggan mana yang dapat menciptakan niat pembelian merek favorit mereka (Lubis et al., 2020).

\subsection{Proses Keputusan Pembelian}

Proses keputusan pembelian adalah proses ketika konsumen menyadari perlunya menentukan produk yang diinginkan. Menurut Kotler \& Armstrong (2009, hlm. 179) "proses pengambilan keputusan pembelian melalui lima tahap, yaitu :

1. Pengenalan masalah, pengenalan masalah muncul ketika ada perbedaan antara kondisi yang diharapkan dan situasi yang sebenarnya. Pemasar perlu menggabungkan informasi dari pelanggan untuk menentukan keadaan yang memicu kebutuhan spesifik.

2. Pencarian informasi, pelanggan harus menggali informasi sebelum memutuskan untuk mengambil barang.

3. Evaluasi alternatif, pelanggan mencoba memenuhi kebutuhannya, pelanggan berusaha untuk mendapatkan keuntungan dari barang dan pelanggan mengamati setiap item ke dalam serangkaian tanda dengan berbagai kemampuan.

4. Keputusan pembelian, pelanggan membuat keputusan pembelian tentang produk yang mereka sukai.

5. Perilaku pasca pembelian, apakah pelanggan puas atau tidak setelah membeli produk".

\subsection{Dimensi Keputusan Pembelian}

Menurut Kotler \& Keller (2009, hlm.178) "Keputusan pembelian ada enam dimensi, yaitu :

1. Seleksi Produk, dalam hal ini perusahaan harus menekankan kepada individu yang ingin membeli barang sehingga pelanggan dapat mencapai keputusan untuk menentukan barang dengan mempertimbangkan kegunaan, manfaatnya.

2. Pemilihan Merek, pelanggan berkewajiban untuk memilih pilihan merek yang akan dibeli, karena setiap perusahaan memiliki merek dengan kualitas dan karakteristik yang berbeda-beda sebagai hasilnya perusahaan juga harus memahami bagaimana pelanggan jatuh terhadap pemilihan merek.

3. Jumlah Pembelian, pelanggan dapat memilih untuk menentukan jumlah produk yang akan dibeli, dalam hal ini perusahaan akan menyediakan kebutuhan konsumen yang berbeda.

4. Waktu Pembelian, pelanggan dapat memilih kapan mereka melakukan pembelian pada waktu yang berbeda yaitu kesesuaian permintaan, manfaat yang dirasakan, dan alasan pembelian.

5. Pemilihan Pemasok, pelanggan berkewajiban untuk menentukan distributor mana yang akan dikunjungi untuk memilih barang untuk menentukan produk yang akan dibeli.

6. Metode Pembayaran, nasabah wajib membayar saat membeli produk biasanya konsumen membayar dengan uang tunai atau kartu kredit tergantung kemampuan konsumen untuk membayar". 


\subsection{Hipotesis}

Hipotesis adalah respons sementara terhadap masalah penelitian. Hipotesis berasal dari kerangka pikiran yang harus diuji secara empiris (termasuk pemahaman, pendapat, prinsip, dan temuan sebelumnya). Oleh karena itu, hipotesis penelitian diusulkan sebagai berikut :

1. Ada pengaruh campuran pemasaran di Dpawon Katering Jakarta.

2. Ada pengaruh pada keputusan pembelian di Dpawon Katering Jakarta.

3. Ada pengaruh marketing mix terhadap keputusan pembelian selama pandemi covid19 di Dpawon Katering Jakarta. .

\section{Material dan Metode}

\subsection{Lokasi dan Waktu Penelitian}

Penelitian ini membahas pengaruh marketing mix terhadap keputusan pembelian di Dpawon Catering yang berlokasi di Jl. Jati No. 23, Kapuk, Kecamatan Cengkareng, Kota Jakarta Barat.

\subsection{Metode Penelitian}

Metode yang digunakan dalam penelitian ini adalah metode kuantitatif menggunakan data deskriptif dan data verifiktif, karena masih ada variabel yang harus diperiksa, tujuan penelitian untuk menggambarkan apa yang terjadi pada objek yang dipelajari dan hubungan antara variabel secara sistematis, benar, dan hati-hati.

Menurut Siyoto dan Sodik dalam (Hardani et.al, 2020, hlm. 240) tujuan metode penelitian kuantitatif adalah "menguraikan dan memanfaatkan metode matematika, pemahaman atau hipotesis yang berkaitan dengan fakta alam. Ini memberikan gambaran umum atau jawaban atas hubungan dasar hubungan kuantitatif".

\subsection{Populasi dan Sampel}

Populasi dalam penelitian ini adalah konsumen yang menggunakan jasa dan merasakan produk Dpawon Katering Jakarta dengan jumlah 41.824 orang pada tahun 2019 - 2020. Sampel pada penelitian ini menggunakan rumus Slovin :

$$
\begin{aligned}
& n=\frac{\mathrm{N}}{1+N e^{2}} \\
& n=\frac{41.824}{1+41.824(0.1)^{2}} \\
& n=\frac{41.824}{419.24}=100
\end{aligned}
$$

Keterangan :

$\mathrm{n} \quad$ = jumlah sampel

$\mathrm{N}$ = jumlah populasi

$\mathrm{e}=$ nilai ukur kesalahan dari ukuran populasi sebesar $10 \%$ atau 0.1 .

Adapun perhitungan ukuran sampel yang digunakan dalam penelitian ini adalah minimal 100 orang responden.

\subsection{Teknik Pengumpulan Data}

Menurut (Sugiyono, 2018, hlm. 219) kuesioner adalah "komposisi yang tercantum pada pertanyaan dan pernyataan yang diberikan kepada responden untuk mendapatkan informasi". Kuesioner berisi pengalaman responden, penilaian responden, karakteristik responden dan jawaban responden, terutama variabel yang menyarankan keputusan pembelian.

\subsection{Jenis dan Sumber Data}

Data primer berasal dari wawancara dengan pemilik, konsumen yang menggunakan jasa Dpawon Katering, selain itu penelitian ini datang melalui kuesioner yang dijawab oleh konsumen yang merupakan responden untuk penelitian ini. 


\section{Hasil dan Diskusi}

\subsection{Responden Data}

Responden dalam penelitian ini sebanyak 100 orang yang didominasi oleh jenis kelamin perempuan $(66 \%)$ dan laki-laki (34\%) dengan rata-rata usia 21-30 tahun persentase sebesar (80\%), kriteria pekerjaan sebagai pegawai swasta terdapat $(37 \%)$ dan pendapatan perbulan rata-rata sebesar $\mathrm{Rp} 2.000 .000-\mathrm{Rp}$ $4.000 .000(41 \%)$.

\subsection{Pengalaman Responden}

Pengalaman responden dalam mengetahui adanya Dpawon katering dari teman atau keluarga sebesar (57\%), penggunaan jasa katering digunakan pada saat acara keluarga (41\%), rata-rata alasan responden dalam menggunakan jasa katering karena tidak mempunyai waktu (58\%), dan biaya transaksi rata-rata $\mathrm{Rp}$ 500.000 - Rp 2.000.000 (44\%).

\subsection{Tanggapan Responden Bauran Pemasaran}

Hasil pengolahan data melalui kuesioner dengan jumlah responden 100 orang, berikut adalah jawaban responden mengenai variabel bauran pemasaran $7 p$ (product, price, place, promotion, process, people, physical evidence)

Tabel 1.

Rekapitulasi Tanggapan Responden Terhadap Bauran Pemasaran

\begin{tabular}{|c|c|c|}
\hline Dimensi & Total Skor & Skor Rata-rata \\
\hline Product & 1.816 & 454 \\
\hline Price & 1.284 & 428 \\
\hline Place & 1.315 & 438,3 \\
\hline Promotion & 1.307 & 435,7 \\
\hline Process & 890 & 445 \\
\hline People & 1.778 & 444,5 \\
\hline Physical Evidence & 1.343 & 447,7 \\
\hline TOTAL & 9.733 & $3.093,2$ \\
\hline
\end{tabular}

sebesar 428.

Berdasarkan tabel 1. mengenai rekapitulasi tanggapan responden dari pengolahan data 100 responden yang telah mengisi kuesioner, diperoleh bahwa total skor sejumlah 9.733 atau skor rata-rata sejumlah 3.093,2.

Hasil rekapitulasi yang memiliki skor tertinggi terdapat pada variabel produk dengan skor rata-rata sebesar 454. Sementara itu, skor terendah terdapat pada variabel harga dengan skor rata-rata
Berikut perhitungan skor terhadap variabel bauran pemasaran dengan membandingkan nilai dari skor ideal yang diperoleh skor maksimum, skor minimum, jarak interval, dan presentase skor.

Mencari nilai indeks maksimum = skor tertingi $\mathrm{x}$ jumlah pernyataan $\mathrm{x}$ jumlah responden $=5 \times 22 \times 100=11.000$

Mencari nilai indeks minimum $=$ skor terendah $\mathrm{x}$ jumlah pernytaan $\mathrm{x}$ jumlah responden $=1 \times 22 \times 100=2.200$ 
Jarak Interval $=$ (nilai maksimum nilai minimum) : banyaknya interval $=$ $(11.000-2.200): 5=1.760$

Persentase skor $=($ total skor : nilai maksimum $) \times 100 \%=(9.733: 11.000) \mathrm{x}$ $100 \%=88,4 \%$

\begin{tabular}{|c|c|c|c|c|}
\hline $\begin{array}{c}\text { Tidak } \\
\text { Baik }\end{array}$ & $\begin{array}{c}\text { Kurang } \\
\text { Baik }\end{array}$ & Cukup & Baik & $\begin{array}{c}\text { Sangat } \\
\text { Bajk }\end{array}$ \\
\hline 00 & & & 9.24 & 11.00 \\
\hline
\end{tabular}

Gambar 2.

Garis Kontinum Bauran Pemasaran

Pada gambar 2 tersebut mengenai garis kontinum variabel bauran pemasaran berada di antara 9.240 dan 11.000 dengan total skor sebesar 9.733. Sehingga tanggapan responden pada variabel bauran pemasaran (X) skor tersebut termasuk ke dalam kategori "sangat baik".

\subsection{Tanggapan Responden} Keputusan Pembelian

Berdasarkan hasil tanggapan responden terhadap keputusan pembelian yang bermaksud untuk mengetahui penilaian keputusan pembelian konsumen di Dpawon katering, berikut adalah tabel mengenai keputusan pembelian :

Tabel 2.

\section{Rekapitulasi Tanggapan Responden Terhadap Keputusan Pembelian}

\begin{tabular}{|l|c|c|}
\hline \multicolumn{1}{|c|}{ Dimensi } & Total Skor & Skor Rata-rata \\
\hline Pemilihan produk & 890 & 445 \\
\hline Pemilihan merek & 839 & 419,5 \\
\hline Jumlah Pembelian & 887 & 443,5 \\
\hline Waktu Pembelian & 453 & 453 \\
\hline Pemilihan Penyalur & 871 & 435,5 \\
\hline Metode Pembayaran & 455 & 455 \\
\hline TOTAL & $\mathbf{4 . 3 9 5}$ & $\mathbf{2 . 6 5 1 , 5}$ \\
\hline
\end{tabular}

Berdasarkan tabel 2. menunjukkan tanggapan responden terhadap keputusan pembelian, pernyataan yang mempunyai skor tertinggi ialah (kemudahan pembayaran menggunakan uang tunai atau credit card) sebesar 455 atau $91 \%$.

Sedangkan pernyataan yang memiliki skor terendah terdapat pada pernyataan (pembelian berdasarkan kepopularitas produk) dengan skor 410 atau $82 \%$ dalam bentuk persentase.

Berikut perhitungan skor terhadap variabel keputusan pembelian dengan membandingkan nilai dari skor ideal yang diperoleh skor maksimum, skor minimum, jarak interval, dan presentase skor.
Mencari nilai indeks maksimum $=$ skor tertinggi $\mathrm{x}$ jumlah pernyataan $\mathrm{x}$ jumlah responden $=5 \times 10 \times 100=5.000$

Mencari nilai indeks minimum $=$ skor terendah $\mathrm{x}$ jumlah pernyataan $\mathrm{x}$ jumlah responden $=1 \times 10 \times 100=1.000$

Jarak interval $=$ (nilai maksimum nilai minimum) : banyaknya interval $=$ $(5.000-1.000): 5=800$

Persentase skor $=($ total skor $:$ nilai maksimum $) \mathrm{x} 100 \%=(4.395: 5.000) \mathrm{x}$ $100 \%=87,9 \%$

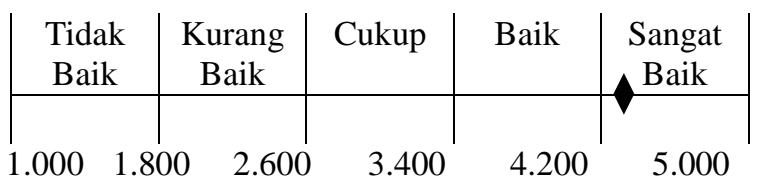

Gambar 3. Garis Kontinum 
Keputusan Pembelian

Pada gambar 3 tersebut mengenai garis kontinum variabel keputusan pembelian berada di antara 4.200 dan 5.000 dengan total skor sebesar 4.395. Sehingga tanggapan responden pada variabel keputusan pembelian (Y) skor tersebut termasuk ke dalam kategori "sangat baik".

\subsection{Hasil Analisis Regresi Linear Berganda}

Tujuan dari analisis regresi linear berganda ialah untuk mengetahui ada atau tidaknya pengaruh bauran pemasaran product $(\mathrm{X} 1)$, price $(\mathrm{X} 2)$, place $(\mathrm{X} 3)$ promotion (X4), process (X5), people (X6), physical evidence (X7) terhadap keputusan pembelian $(\mathrm{Y})$ :

a. Hasil perhitungan konstanta sejumlah 9,788 yang berarti variabel product $(\mathrm{X} 1)$, price (X2), place (X3), promotion (X4), process (X5), people (X6), physical evidence (X7) hasilnya ialah 0 , sehingga nilai pada keputusan pembelian adalah 9,788.

b. Hasil koefisien pada product (X1) sejumlah 0,670 yang artinya apabila beralih menjadi $1 \%$ dan anggapan variabel independen nilainya tetap, maka keputusan pembelian (Y) akan mengalami peningkatan sebesar 0,670. Sehingga hasil koefisien product bernilai positif atau memiliki pengaruh positif atas keputusan pembelian.

c. Hasil koefisien pada price (X2) sejumlah 0,049 yang artinya apabila beralih menjadi $1 \%$ dan anggapan variabel independen nilainya tetap, maka keputusan pembelian (Y) akan mengalami peningkatan sebesar 0,049 . Sehingga hasil koefisien price bernilai positif atau memiliki pengaruh positif atas keputusan pembelian

d. Hasil koefisien pada place (X3) sejumlah $-0,189$ yang artinya apabila variabel bebas price mendapati kenaikan $1 \%$ dan anggapan variabel independen nilainya tetap, maka keputusan pembelian (Y) akan mengalami pengurangan sebesar $-0,189$. Sehingga hasil koefisien place bernilai negatif atau memiliki pengaruh negatif atas keputusan pembelian.

e. Hasil koefisien pada promotion (X4) sejumlah 0,182 yang artinya apabila beralih menjadi $1 \%$ dan anggapan variabel independen nilainya tetap, maka keputusan pembelian (Y) akan mengalami peningkatan sebesar 0,182 . Sehingga hasil koefisien promotion bernilai positif atau memiliki pengaruh positif atas keputusan pembelian

f. Hasil koefisien pada process (X5) sejumlah 0,981 yang artinya apabila beralih menjadi $1 \%$ dan anggapan variabel independen nilainya tetap, maka keputusan pembelian (Y) akan mengalami peningkatan sebesar 0,981. Sehingga hasil koefisien process bernilai positif atau memiliki pengaruh positif atas keputusan pembelian

g. Hasil koefisien pada people (X6) sejumlah 0,214 yang artinya apabila beralih menjadi $1 \%$ dan anggapan variabel independen nilainya tetap, maka keputusan pembelian (Y) akan mengalami peningkatan sebesar 0,214 . Sehingga hasil koefisien people bernilai positif atau memiliki pengaruh positif atas keputusan pembelian

h. Hasil koefisien pada physical evidence (X7) sejumlah 0,667 yang artinya apabila beralih menjadi $1 \%$ dan anggapan variabel independen nilainya tetap, maka keputusan pembelian (Y) akan mengalami peningkatan sebesar 0,667. Sehingga hasil koefisien physical evidence bernilai positif atau memiliki pengaruh positif atas keputusan 
pembelian.

\subsection{Hasil Analisis Korelasi dan Koefisien Determinasi}

Hasil analisis korelasi (R) antar variabel bauran pemasaran dengan keputusan pembelian di Dpawon katering sebesar 0,796 hasil analisis korelasinya berada diantara $0,60-0,799$ sehingga hal ini menunjukkan bahwa tingkat hubungan bauran pemasaran dan keputusan pembelian dikatakan "kuat".

Sementara itu, hasil koefisien determinasi menunjukkan bahwa nilai $\mathrm{R}$ square sebesar 0,633 sehingga nilai tersebut dalam bentuk persen menjadi $(0,633 \times 100 \%)$ yaitu $63,3 \%$ yang artinya variabel bauran pemasaran product (X1), price $(\mathrm{X} 2)$, place $(\mathrm{X} 3)$, promotion $(\mathrm{X} 4)$, process (X5), people (X6), physical evidence (X7) memiliki pengaruh yang positif terhadap keputusan pembelian. Sedangkan nilai sisanya 0,367 berasal dari variabel yang tidak diteliti dalam penelitian ini.

\subsection{Hasil Uji F}

Hasil uji f dapat diperoleh bahawa $F_{\text {hitung }}$ ialah 22.688 sementara itu $\mathrm{F}_{\text {tabel }}$ ialah 2,11 dari tabel F 0,005. Sehingga hasil pengujian menunjukkan bahwa nilai signifikan sebesar 0,00 yang berarti nilai tersebut lebih kecil dari 0,05. Kemudian $F_{\text {hitung }} 22.688$ lebih besar dari $F_{\text {tabel }} 2,11$ maka hasil tersebut menunjukkan bahwa $\mathrm{H}_{0}$ ditolak dan $\mathrm{H}_{\mathrm{a}}$ diterima. Oleh karena itu model regresi ini dapat disimpulkan bahwa variabel bauran pemasaran berpengaruh signifikan terhadap variabel keputusan pembelian.

\subsection{Hasil Uji T}

Uji t bertujuan untuk membuktikan ada atau tidaknya variabel bebas yang mempunyai pengaruh secara sendiri (parsial) terhadap variabel terikat $(\mathrm{Y})$ :

a. Variabel Product (X1)

Pada variabel product memiliki pengaruh yang signifikan terhadap keputusan pembelian dengan nilai $t_{\text {hitung }} 2.744$ lebih besar dari tabel 1.986 atau $2.744>1.986$ maka $\mathrm{H}_{0}$ ditolak dan $\mathrm{H}_{\mathrm{a}}$ diterima. Sehingga variabel product memiliki pengaruh yang signifikan terhadap keputusan pembelian di Dpawon katering.

b. Variabel Price (X2)

Pada variabel price tidak memiliki pengaruh yang signifikan terhadap keputusan pembelian dengan nilai $t_{\text {hitung }} 0.197$ lebih kecil dari tabel 1.986 atau $0.197<1.986$ maka $\mathrm{H}_{0}$ diterima dan $\mathrm{H}_{\mathrm{a}}$ ditolak. Sehingga variabel price tidak memiliki pengaruh yang signifikan terhadap keputusan pembelian di Dpawon katering.

c. Variabel Place (X3)

Pada variabel place tidak memiliki pengaruh yang signifikan terhadap keputusan pembelian dengan nilai $\mathrm{t}_{\text {hitung }}-0.719$ lebih kecil dari $\mathrm{t}_{\text {tabel }} 1.986$ atau $-0.719<1.986$ maka $\mathrm{H}_{0}$ diterima dan $\mathrm{H}_{\mathrm{a}}$ ditolak. Sehingga variabel place tidak memiliki pengaruh yang signifikan terhadap keputusan pembelian di Dpawon katering.

d. Variabel Promotion (X4)

Pada variabel promotion tidak memiliki pengaruh yang signifikan terhadap keputusan pembelian dengan nilai thitung 0.729 lebih kecil dari $t_{\text {tabel }}$ 1.986 atau $0.729<1.986$ maka $\mathrm{H}_{0}$ diterima dan $\mathrm{H}_{\mathrm{a}}$ ditolak. Sehingga variabel promotion tidak memiliki pengaruh yang signifikan terhadap keputusan pembelian di Dpawon katering.

e. Variabel Process (X5)

Pada variabel process memiliki pengaruh yang signifikan terhadap keputusan pembelian dengan nilai $t_{\text {hitung }} 2.438$ lebih besar dari $t_{\text {tabel }} 1.986$ atau $2.438>1.986$ maka $\mathrm{H}_{0}$ ditolak dan $\mathrm{H}_{\mathrm{a}}$ diterima. Sehingga variabel process memiliki pengaruh yang signifikan terhadap keputusan pembelian di Dpawon katering.

f. Variabel People (X6) 
Pada variabel people tidak memiliki pengaruh yang signifikan terhadap keputusan pembelian dengan nilai thitung 0.826 lebih kecil dari tabel 1.986 atau $0.826<1.986$ maka $\mathrm{H}_{0}$ diterima dan $\mathrm{H}_{\mathrm{a}}$ ditolak. Sehingga variabel people tidak memiliki pengaruh yang signifikan terhadap keputusan pembelian di Dpawon katering.

g. Variabel Physical Evidence (X7)

Pada variabel physical evidence memiliki pengaruh yang signifikan terhadap keputusan pembelian dengan nilai thitung 2.348 lebih besar dari tabel 1.986 atau $2.348>1.986$ maka $\mathrm{H}_{0}$ ditolak dan $\mathrm{H}_{\mathrm{a}}$ diterima. Sehingga variabel physical evidence memiliki pengaruh yang signifikan terhadap keputusan pembelian di Dpawon katering.

Berdasarkan hasil uji tersebut variabel yang memiliki pengaruh signifikan terhadap keputusan pembelian ialah variabel product, process, physical evidence. Sedangkan variabel yang tidak memiliki pengaruh signifikan terhadap keputsuan pembelian ialah variabel price, place, promotion, people.

\subsection{Hasil Pembahasan}

Hasil penelitian ini dilakukan untuk mengetahui pengaruh bauran pemasran terhadap keputusan pembelian di Dpawon Katering Jakarta. Maka dapat dilihat sebagai berikut :

1. Produk (X1)

Variabel produk memberikan kualitas produk, variasi produk, penyajian produk, rasa makanan produk sudah sesuai dengan kebutuhan dan keinginan konsumen. Disisi lain variabel produk dalam hasil pengujian analisis uji t memiliki nilai signifikan terhadap keputusan pembelian dan hasil koefisien produk bernilau positif atas keputusan pembelian.

2. Harga (X2)
Variabel harga yang ditawarkan Dpawon katering sudah berada dikategori sangat baik dengan nilai persentase $85,6 \%$. Tetapi pada pengujian analisis uji $t$ tidak mempunyai nilai signifikan terhadap keputusan pembelian. Hal ini menunjukkan harga yang ditawarkan terbilang masih mahal dibanding katering lain.

3. Lokasi (X3)

Variabel lokasi memiliki nilai persentase $87,6 \%$ diperoleh Dpawon catering memberikan kemudahan dalam menawarkan jasa antar. Namun hasil pengujian $t$ variabel tersebut tidak memiliki pengaruh yang signifikan terhadap keputusan pembelian dan memiliki nilai negative terhadap nilai koefisien. Hal tersebut terjadi karena lokasi Dpawon katering kurang strategis berada ditengah-tengah padat penduduk.

4. Promosi (X4)

Variabel promosi memperoleh persentase sebesar $87,1 \%$ didapatkan dari Dpawon catering memberikan informasi mengenai promosi lewat media sosial, website dan brosur. Hasil pengujian analisis uji t tidak memiliki pengaruh yang signifikan terhadap keputusan pembelian. Hal ini terjadi karena Dpawon kurang memberikan diskon atau potongan harga.

5. Proses (X5)

Variabel proses memiliki nilai persentase $89 \%$. Hasil pengujian uji $\mathrm{t}$ memiliki pengaruh yang signifikan dan nilai koefisien memiliki nilai positif terhadap keputusan pembelian. Hal ini diperoleh karena Dpawon memiliki pelayanan yang baik terhadap konsumennya sehingga meningkatkan kepuasan konsumen.

6. Orang (X6)

Variabel orang atau sdm memperoleh nilai persentase $88,9 \%$ karena penampilan karyawan rapih dan bersih dalam mengantarkan makanan. Tetapi 
pada analisis uji $\mathrm{t}$ tidak memiliki pengaruh yang signifikan terhadap keputusan pembelian karena kurangnya wawasan karyawan dalam menawarkan produknya.

7. Bukti Fisik (X7)

Variabel bukti fisik mendapatkan nilai 89,5\% diperoleh dari area makanan yang disajikan bersih. Namun hasil uji t memperoleh hasil bahwa bukti fisik berpengaruh signifikan terhadap keputusan pembelian karena mengindikasikan penataan dalam menyajikan produk sudah menarik dan terlihat rapih.

8. Hasil pengujian koefisien determinasi variabel bauran pemasaran memiliki pengaruh positif terhadap variabel keputusan pembelian. Artinya hasil penelitian ini bahwa semakin baik variabel bauran pemasran maka keputusan pembelian produk akan semakin naik.

\section{Kesimpulan}

\subsection{Kesimpulan}

Akibat kondisi pandemi covid19 ini, memberikan dampak terhadap menurunnya omset penjualan Dpawon Katering Jakarta karena dilarangnya beraktivitas diluar rumah yang umumnya dilakukan bertatap muka. Dengan munculnya kondisi tersebut, usaha jasa boga seperti Dpawon katering mengalami kesulitan dalam menjangkau target pasar. Hal ini membawa dampak terhadap finansial perusahaan, yang kemungkinan besar perusahaan membuat keputusan untuk pemecatan karyawan. Maka dari itu diperoleh kesimpulan sebagai berikut :

1. Bauran pemasaran sebagai variabel bebas yang terdiri dari $7 p$ yaitu product (X1) diterangkan bahwa kualitas produk ditawarkan pada saat pandemi ini sudah sesuai standar yang ditentukan, price (X2) namun dalam penentuan harga masih tergolong mahal dikarenakan perekonomian saat ini mengalami penurunan yang sangat tajam yang berdampak pada menurunya daya beli masyarakat, place (X3) Dpawon katering berada di pemukiman padat penduduk apalagi dengan kondisi pandemi saat ini membuat lokasi tersebut tidak terlihat oleh calon konsumen karena sebagian masyarakat keluar rumah hanya melewati jalan utama saja untuk keperluannya, promotion (X4) kurangnya dalam mempromosikan dan memberikan diskon atau potongan harga yang akibatnya berkurangnya minat calon konsumen untuk melakukan pembelian di Dpawon tersebut, process (X5) pelayanan yang diberikan sudah sangat baik dalam melayani calon konsumen, people (X6) terbilang masih kurang terampil dan kurangnya pengetahuan di bidang jasa boga diikuti dengan situasi seperti ini dapat mengakibatkan menurunnya kepuasan terhadap calon konsumen, Sementara itu physical evidence (X7) fasilitas Dpawon katering sudah tersedia dengan baik dan lengkap sesuai standar yang ditetapkan.

2. Pengambilan keputusan pembelian diperoleh dari pemilihan merek, karena minimnya dalam memasarkan produk untuk menggunakan media sosial, jasa iklan dan minimnya dalam mengusulkan potongan harga sebagai media pemasaran. Sehingga kesadaran konsumen dalam mengingat merek produk berkurang karena kurangnya aktivitas dalam memasarkan produk.

3. Bauran pemasaran memiliki pengaruh yang signifikan terhadap keputusan pembelian. Hal ini membuktikan bagi pengelola katering untuk mempertahankan kualitas produk yang diberikan, memberikan pelayanan yang ramah, fasillitas yang lengkap, dan mengupayakan dalam memasarkan produk untuk menarik perhatian calon konsumen, memberikan harga yang sesuai standar dengan kualitas yang 
diberikan, mengupayakan lokasi yang strategis serta meningkatkan pengetahuan dan pelatihan terhadap karyawan.

4. Strategi untuk meningkatkan keputusan pembelian dengan memodifikasi produk yang ditawarkan, mempertahankan kebersihan dalam kualitas produk, memanfaatkan media sosial pada saat pandemi dalam memasarakan produknya karena dengan kondisi ini umumnya masyarakat banyak melakukan aktivitas didalam rumah, serta memaksimalkan dalam memberikan pelayanan yang terbaik untuk konsumen.

\subsection{Saran}

Diharapkan Dpawon katering melakukan pengembangan dan inovasi terhadap strategi pemasarannya. Meningkatkan kualitas produk untuk menarik konsumen, Melakukan perubahan harga supaya dapat bersaing dengan katering lain tanpa mengurangi kualitas produk dengan mempertimbangkan kondisi pandemi saat ini, Memberikan arahan petunjuk lokasi supaya mudah terlihat calon konsumen pada saat mengunjunginnya, Memberikan potongan harga atau diskon supaya konsumen mudah terpikat, Mempertahankan pelayanan terhadap konsumen agar konsumen merasa puas, Memberikan pelatihan dan pengetahuan pegawai supaya dapat menjelaskan produk yang ditawarkan serta pegawai tetap mematuhi protokol kesehatan, Lalu meninjau kembali dalam penataan produk yang disajikan.

\section{Referensi}

Indriasari, D. P. 2017. Pengaruh Harga, Promosi Dan Produk Terhadap Keputusan Pembelian Konsumen
Pada Restoran Cepat Saji. Jurnal Ekonomi, 19(3): 290-298. eissn : 2621-8925

Kotler, Philip \& Keller, K.L., 2009. Manaejemn Pemasaran. Edisi Ketigabelas. Jilid Pertama. Jakarta: Erlangga.

Lubis, A. T., Irawati, N., \& Sembiring, K. B. F. 2020. The Impact of life style and social media on purchasing decisions in B-One cafe, Medan. International Journal of Research and Review, 7(February), 32-40.

Shahhosseini, A., \& Tohidy Ardahaey, F. 2011. Marketing Mix Practices in the Cultural Industry. International Journal of Business and Management, 6(8): 230-234. Doi: https://doi.org/10.5539/ijbm.v6n8p2 $\underline{30}$

Kotler, P., \& Armstrong, G. 2008. Prinsip-prinsip Pemasaran, Jilid 1. Jakarta : Erlangga.

Shinta, A. 2011. Manajemen Pemasaran. Malang: Tim UB Press.

Wulan, Mawardi, P. (2016). Pengaruh Bauran Pemasaran Jasa Terhadap Keputusan Pembelian Serta Dampaknya Terhadap Keputusan Pelanggan (Studi pada Resoran Kayu Manis Tuban). Jurnal Administrasi Bisnis, 2(38), 176-183. Doi: https://doi.org/https://doi.org/10.369 87/ecobi.v1i2.22.

Pertiwi, M. I., Yulianto, E., \& Sunarti. 2016. Pengaruh Bauran Pemasaran Terhadap Keputusan Pembelian (Survei pada Konsumen Baker' s King Donuts \& Coffee di MX Mall Malang ). Jurnal Administrasi Bisnis (JAB), 37(1), 179-186. 
Naibaho, E. R., Fauzi, A., \& Sadalia, I. 2020. The Effect of Marketing Mix on Satisfaction of Customer Insurance Products Unit Link (Empirical Study in PT AIA Financial Branch Phoenix Medan). International Journal of Research, 7(2): 47-55. eissn : 2349-9788.

Halim, F. et.al., 2021. Manajemen Pemasaran Jasa. Edisi Pertama. Yayasan Kita Menulis.

Tresyanto, C. A., \& Panjaitan, T.W.S. 2017. Pemasaran Jasa. Edisi Pertam. Jakad Media Publishing.

Sudirman, A. et.al., 2020. Perilaku Konsumen dan Perkembangan di Era Digital. Cetakan Pertama. Bandung: Widina Bhakti Persada.

Kotler Armstrong. 2009. Prinsip-Prinsip Pemasaran Edisi Jilid 1 \& 2. Erlangga.

Kotler \& Keller. 2009. Manajemen Pemasaran (Ketigabela). Erlangga.

Hardani et.al., 2020. Metode Penelitian Kualitatif dan Kuantitatif. Cetakan Pertama. Yogyakarta: Pustaka Ilmu Grup.

Sugiyono. 2018. Metode Penelitian Kuantitaif. Cetakan Pertama. Bandung: Alfabeta. 